\title{
Analysis of the coefficient of linear relationship, generated by the exponential heating during the welding process for an A36 steel plate
}

\section{Análisis del coeficiente de relación lineal, generado por el calentamiento exponencial durante el proceso de soldadura para una placa de acero A36}

\author{
BARRERA-MORENO, Mario Alberto $\dagger^{*}$, SERVIN-CASTAÑEDA, Rumualdo, CALDERON- \\ RAMOS, Ismael and PEREZ-ALVARADO Alejandro
}

Universidad Autónoma de Coahuila, Facultad de Ingeniería Mecánica y Eléctrica, Monclova, Coahuila

ID $1^{\text {st }}$ Author: Mario, Barrera-Moreno / ORC ID: 0000-0003-4772-7795

ID $1^{\text {st }}$ Co-author Rumualdo, Servin-Castañeda / ORC ID: 0000-0002-8655-2572

ID $2^{\text {nd }}$ Co-author: Ismael, Calderon-Ramos / ORC ID: 0000-0003-4635-7630

ID $3^{\text {rd }}$ Co-author: Alejandro, Perez-Alvarado / ORC ID: 0000-0003-0420-5153

DOI: $10.35429 /$ JTIP.2021.13.5.16.21

Received July 30, 2021; Accepted October 30, 2021

\begin{abstract}
The present study presents the relationship of temperature and deformation as well as the analysis of heat transfer and deformation produced during welding of a steel plate. The method consists of strategically welding a base metal plate (A-36) with a high-hardness filler material to obtain an overall increment in wear resistance. However, the thermal cycles generated during welding produced deformation, thus changing the flatness of the plate. Different sequences of welding were applied to obtain a relationship between the heat transfer and deformation. A filler material was applied to 100 holes (1/2" diameter and $8 \mathrm{~mm}$ depth) in a $1 / 2$ " steel plate. The temperature and deformation were measured for 3 different welding sequences. Plate 1 reached a final mean temperature of 467 ${ }^{\circ} \mathrm{C}$ and deformation of 0.016 ", plate 2 reached $472.9^{\circ} \mathrm{C}$ and -0.008 ", and plate 3 reached $354.2^{\circ} \mathrm{C}$ and $0.020^{\prime \prime}$. The results indicate that the deformation is not function of the final temperature, instead the deformation is function of the slope of the curve temperature vs deformation. The behavior of the curve temperature vs deformation is linear for all cases studied, confirming the findings of the lowest deformation for plate 2 which exhibited the lowest slope.
\end{abstract}

Temperatura, Deformation, Linear equation

\begin{abstract}
Resumen
El presente estudio consiste en establecer la proporcionalidad de temperatura con la deformación que se produce en un proceso de soldadura para desarrollar una ecuación que establezca la relación que existe entre los ciclos térmicos y la deformación generada. El desarrollo consiste en utilizar un metal base resistente mecánicamente como el acero A36, y aplicarle en puntos estratégicos soldadura; sin embargo, los ciclos térmicos generados producen deformación que afecta la planeza, la placa de acero A-36 es de $1 / 2$ " de espesor, que se diseña con 100 taladros de $1 / 2$ " de diámetro por $8 \mathrm{~mm}$ de profundidad, Las deformaciones obtenidas fueron de comportamiento lineal para las tres probetas, obteniendo temperaturas promedio, para probeta 1 de $467.6^{\circ} \mathrm{C}$ y deformación de 0.016 ", probeta 2 de $472.9^{\circ} \mathrm{C}$ y deformación de $-0.008^{\prime \prime}$ y probeta 3 de $354.2^{\circ} \mathrm{C}$ y deformación de 0.020 ", lo que nos indica que la deformación no está en función de la temperatura final, sino en la proporcionalidad del calentamiento con la deformación, de acuerdo con la ecuación $y=a+b x$; dando como resultado que la probeta 2 es la que se deforma menos, coincidiendo con la menor pendiente de la gráfica lineal y el coeficiente de relación lineal más cercana a la unidad absoluta.
\end{abstract}

Temperatura, Deformación, Ecuación lineal

Citation: BARRERA-MORENO, Mario Alberto, SERVIN-CASTAÑEDA, Rumualdo, CALDERON-RAMOS, Ismael and PEREZ-ALVARADO Alejandro. Analysis of the coefficient of linear relationship, generated by the exponential heating during the welding process for an A36 steel plate. Journal of Technologies in Industrial Processes. 2021. 5-13: 16-21

\footnotetext{
* Author Correspondence (mariobarrera@uadec.edu.mx)

$\dagger$ Researcher contributing as first author.
} 


\section{Introduction}

A weld, according to the definition of the American Welding Society (American Welding Society, 2010), is a process of joining metals by the action of heat, with or without the addition of new metallic material, giving continuity to the joined elements (American Welding Society 2010). The filler material and heat supply applied in the welding process can affect the properties of the part, generating imperfections such as porosities, cracks and deformations. To avoid these effects it is necessary to establish parameters to minimize them.

Steels are materials that have many advantages in terms of mechanical properties, corrosion resistance and weldability. However, when steels are welded, the thermal cycle of welding causes alterations in the composition, distribution, size and volume fraction of the materials through dissolution, growth and precipitation of the materials. (Marconi et al. 2015 and Lopez et al. 2013), state that in welding processes, the heat input is a relative measure of the energy transferred to the components to be welded, in general the final microstructure is a function of the chemical composition and thermal cycle, and in turn the latter, is a function of the heat input and the geometric component (amount of material to be welded). This leads to the welding zone generating a thermal affectation in the material where it generates a field of residual stresses, as well as a difference in mechanical properties, tenacity and mechanical resistance.

One of the main sectors that generate a great source of employment in Mexico is the mining, steel and cement industries, where the use of hard wear-resistant materials is an important part of the raw material transportation process. Currently, the anti-wear steels developed are highly expensive, so the development of hard coatings applied by a welding process is a possible solution. For this reason, it is necessary to analyze the significant variables on which the final quality of this material depends.

When applying heat generated in a welding process, deformation occurs due to heat and temperature changes; when the distribution of heat generated is controlled, deformation should be minimal and the steel plate should keep its flatness.
The ratio of the amount of heat input in a welding process is highly related to the deformation that can possibly be obtained as a final result. Deformation in a weld is due to nonuniform expansion and contraction of both the adjacent base metal and the filler metal during the heating/cooling cycle. During the heating/cooling cycle, many factors are involved, making it difficult to make accurate predictions of deformation. The physical and mechanical properties of the metal on which the calculations are based. For example, as the welding temperature increases, the yield strength, modulus of elasticity, and thermal conductivity of the material decrease, and the coefficient of thermal expansion and specific heat increase.

These changes, in turn, affect heat flow and uniformity of distribution, so these variables make an accurate calculation of what happens during heating and cooling complicated. (Electric L. Weld Distortion 2018), specifies that even if the calculation is simple, in the design phase and in the shop, a practical understanding of the causes of deformations, the effects of shrinkage on various types of welded joints, methods to control shrinkage, and the advantageous use of shrinkage is important.

In a welded joint, the same forces of expansion and contraction act on the weld metal and the base metal. When the welded metal solidifies and melts with the base metal, it is in its maximum state of expansion, occupying the maximum possible volume as a solid. On cooling, it tries to contract to reach the volume it normally occupies at low temperatures, but is restrained by the adjacent base metal. The stresses developed in the weld have finally reached the creep of the base metal. At this point, the weld stretches, or flows, conforming to the volume requirements at the lower temperature. But only those stresses that exceed the yield strength of the weld metal are relieved by this accommodation.

(Flores et al. 2006), states that when the weld reaches room temperature, assuming full restraint of the base metal, it exhibits internal tensile stresses approximately equal to the yield strength of the metal. If the restraints (clamps holding the workpiece, or an opposing shrinkage force) are removed, the internal stresses are partially relieved, causing movement of the base metal, i.e., deformation. 
(Radaj et Al. 1992 and Guangming et Al. 2015), specify that the welding sequence is one of the most significant variables in the deformation suffered, since the same residual stress of the welding process the smaller the welding process the greater its deformation, and the greater the stress the smaller its deformation.

(Bullon W., et al. 2010) indicates that in the welding process different physical phenomena occur as a consequence of the interaction in the thermal fields that generate mechanical deformations and alterations to the microstructural state. The temperature field is a function of many welding parameters, such as: arc power (116-118 Amperes), welding speed (40 cm/min), welding sequence (flat) and environmental conditions $\left(30^{\circ} \mathrm{C}\right)$. The residual stress deformation and distortions in welding depend on interrelated factors such as: thermal field, material properties, edge conditions, weld type and welding conditions.

\section{Research Methodology}

In order to analyze the heat transfer and determine the deformation in the welding application on the specimens, a methodology is proposed to determine the heat distribution in the specimen and the existing deformation once the welding application is finished. The proposed method provides an insight to take into account which sequence is ideal to minimize the deformation effects.

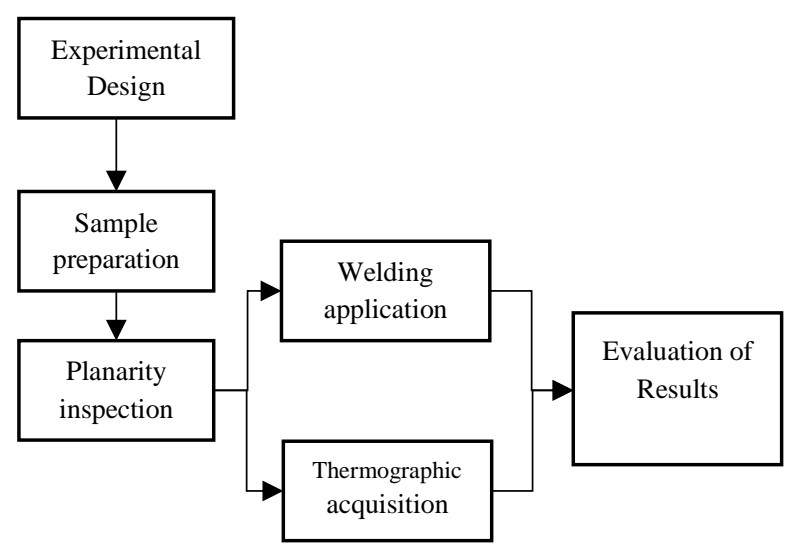

Figure 1 Diagram of the proposed method for deformation analysis in the application of welding on specimens

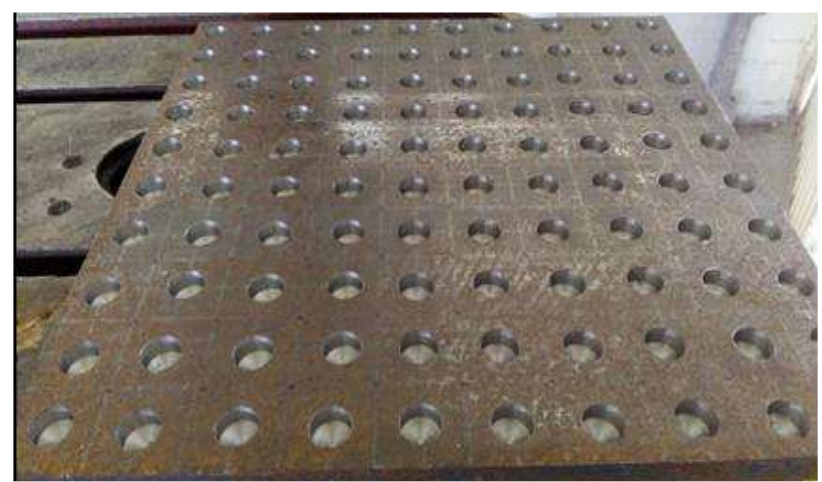

Figure 2 Sample preparation, physical representation of the experimental design

To identify the points where the flatness is measured, the following relationship is used; the plate is divided into columns and rows, in sections consisting of nine columns named with the letters A, B, C, D, E, F, G, H, I. and nine rows consisting of $1,2,3,4,5,6,7,8,9$, forming eighty-one intersections, as shown in Figure 3; For example, the intersections D8, E2 and I7 are identified in red circle.

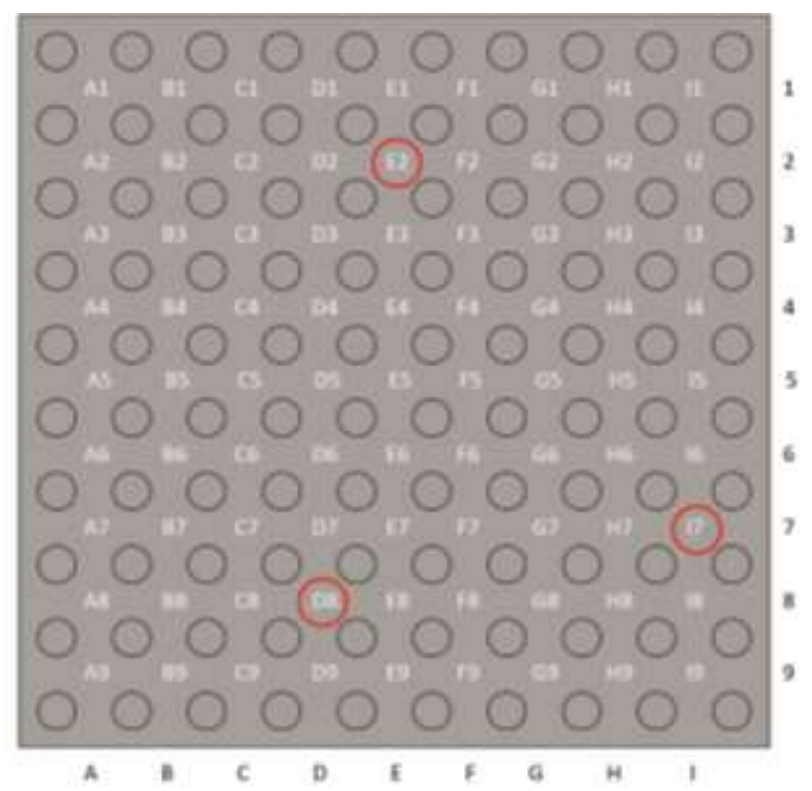

Figure 3 Identification of intersections

Applying the dimensional inspection method, in the flatness inspection stage, measurements are taken at the 81 intersections before and after applying the weld, in order to monitor the deformation produced throughout the process. With the help of a caratula indicator, by running it along all the lines of the grid drawn on each of the three plates.

In order to measure the flatness considering different heating parameters, due to the large amount of heat generated in the welding process, sequences were established for the application of welding on the plate.

BARRERA-MORENO, Mario Alberto, SERVIN-CASTAÑEDA, Rumualdo, CALDERON-RAMOS, Ismael and PEREZ-ALVARADO Alejandro. Analysis of the coefficient of linear relationship, generated by the exponential heating during the welding process for an A36 steel plate. Journal of Technologies in Industrial Processes. 2021 
In order to determine which of them allow to obtain the least deformation, for this 5 different sequences are established for the application of the filler metal, which are established as follows:

1) Sequence 1 consists of 36 drill holes.

2) Sequence 2 consists of 20 holes

3) Sequence 3 consists of 4 holes

4) Sequence 4 consists of 28 holes

5) Sequence 5 consists of 12 holes

The experimental designs of the 5 different sequences randomly established for the 3 plates are shown in Figure 4, Figure 5 and Figure 6.

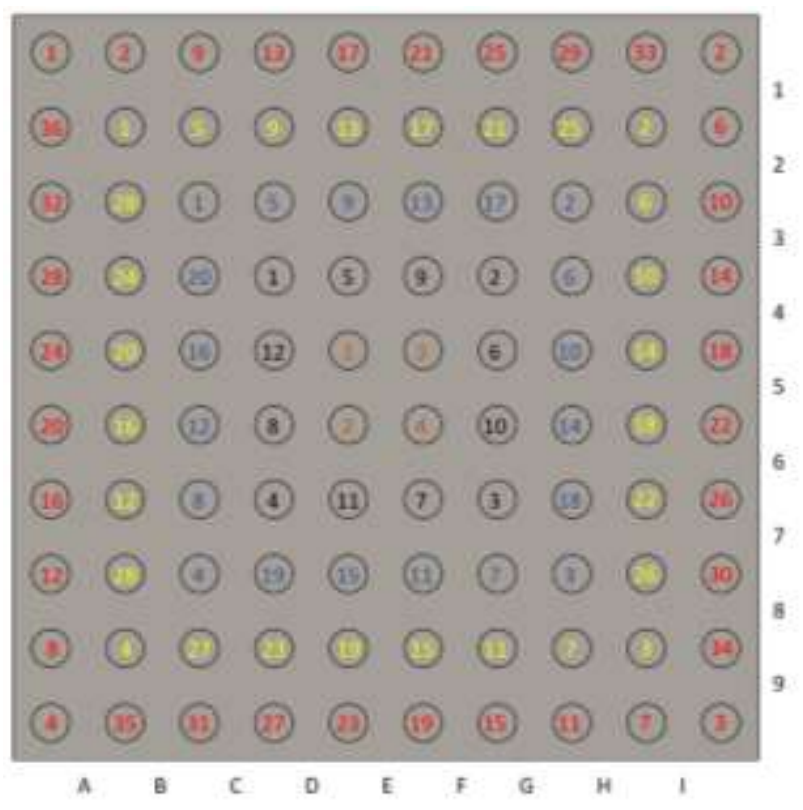

Figure 4 Sequences established for plate

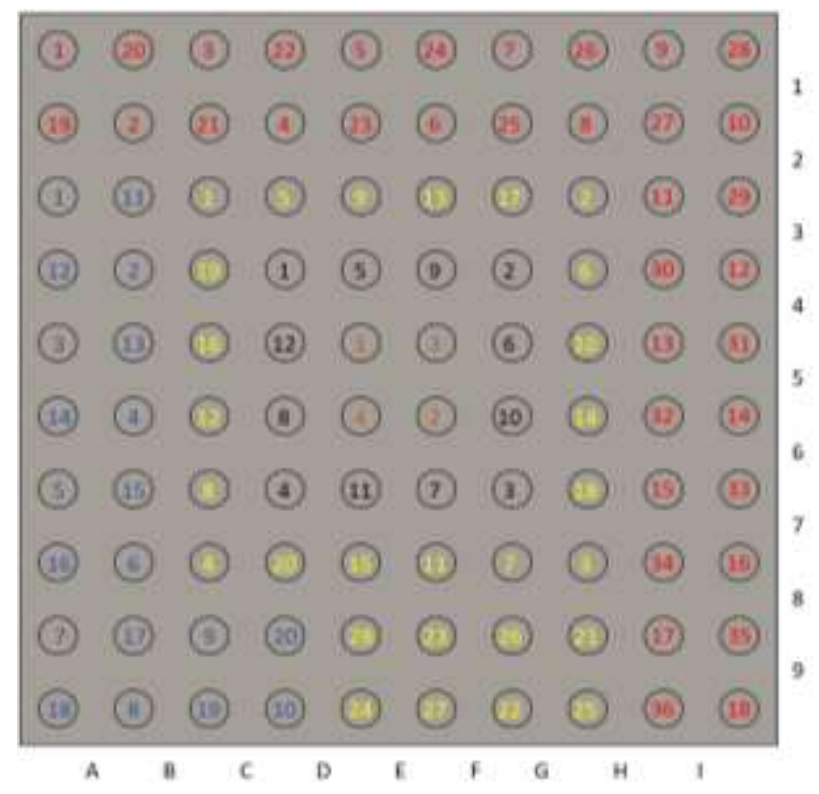

Figure 5 Sequences established for plate 2

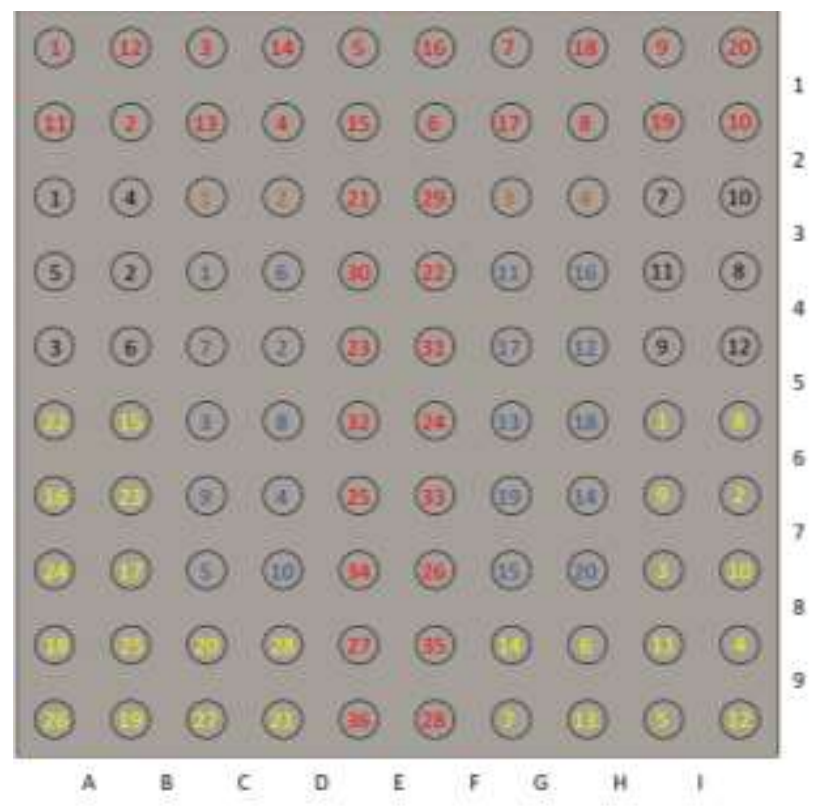

Figure 6 Sequences established for plate 3

For the welding application on the three plates, the same SMAW electric arc welding process is used, with a MILLER welding machine and an AWS A5.1 class E6013 electrode. An amperage of 116-118 A, direct current with positive electrode is applied. The filler metal used in this process is the 1/8 E6013 coated electrode, whose characteristics are $60000 \mathrm{lb} / \mathrm{plg}^{2}$ of minimum tensile strength.

A Fluke thermographic camera was used to take thermographies, taking images after each welding sequence applied to each of the plates. Finally, the analysis and evaluation of the results are discussed in the conclusions stage.

\section{Results}

Using a caratula indicator, the flatness of the 3 plates was measured before and after the welding process, the average of the deformation data generated is expressed in Table 1 and the linear equation obtained in each of the graphs shown in Figure 7, Figure 8 and Figure 9, which indicate the behavior of the deformation vs. temperature in the sequence applied in each plate.

\begin{tabular}{|l|r|r|}
\hline \multicolumn{3}{|c|}{ Plate flatness, base metal average (inches) } \\
\hline Probe & Before & \multicolumn{1}{c|}{ After } \\
\hline Plate 1 & 0.00096 & -0.01515 \\
\hline Plate 2 & -0.00001 & 0.00880 \\
\hline Plate 3 & 0.00490 & -0.01588 \\
\hline
\end{tabular}

Table 1 Deformation results of the three plates 


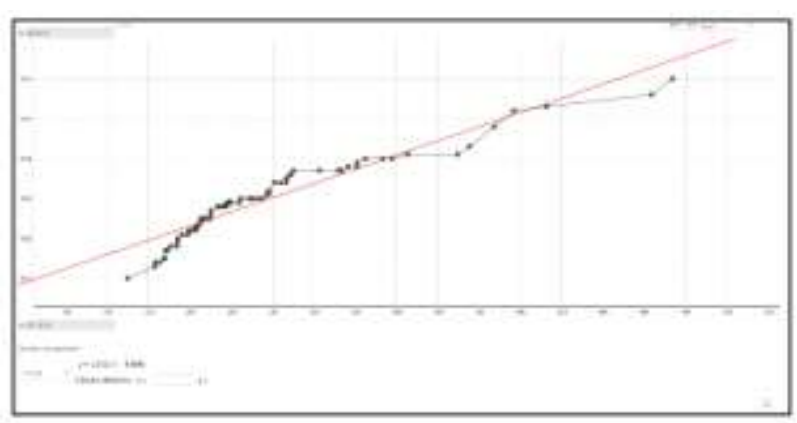

Figure 7 Graph showing the linear behavior of strain vs. temperature, Plate 1

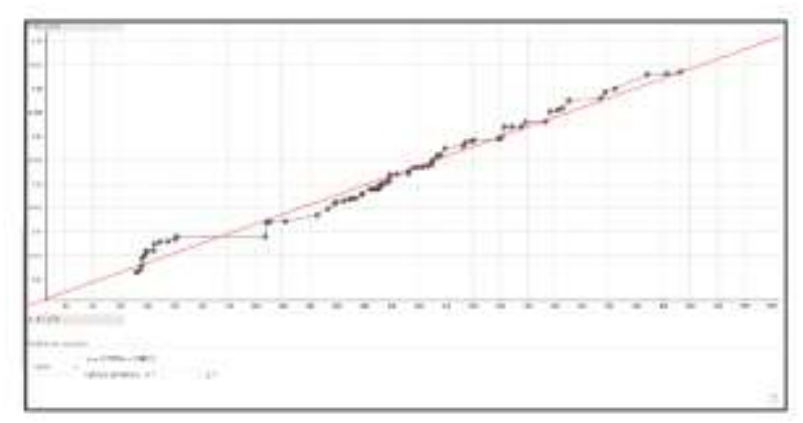

Figure 8 Graph showing the linear behavior of deformation vs. temperature Plate 2

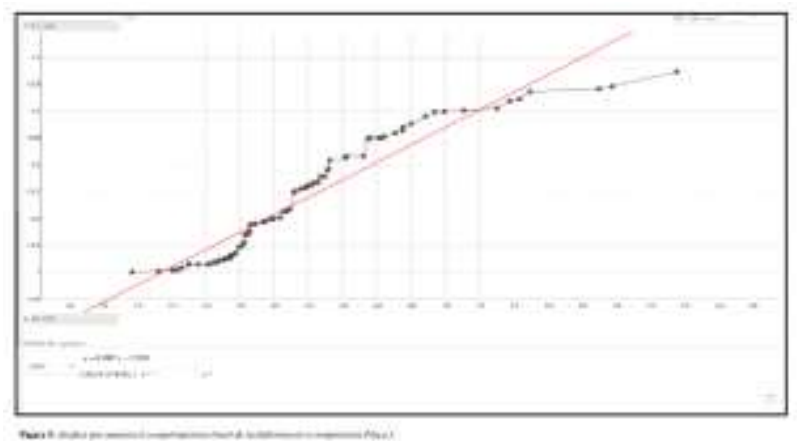

Figure 9 Graph showing linear behavior of strain vs. temperature Plate 3

With the use of the Fluke thermal graphic camera and the support of the Smart View software, the thermographic images of each of the five sequences for the three plates were obtained, however, in Figure 10, only the thermographies of sequence 5 for the three plates are shown and described, since the thermal response is a function of the applied sequence and really for the final evaluation sequence five is the one that concentrates the heat generated during the first four sequences.

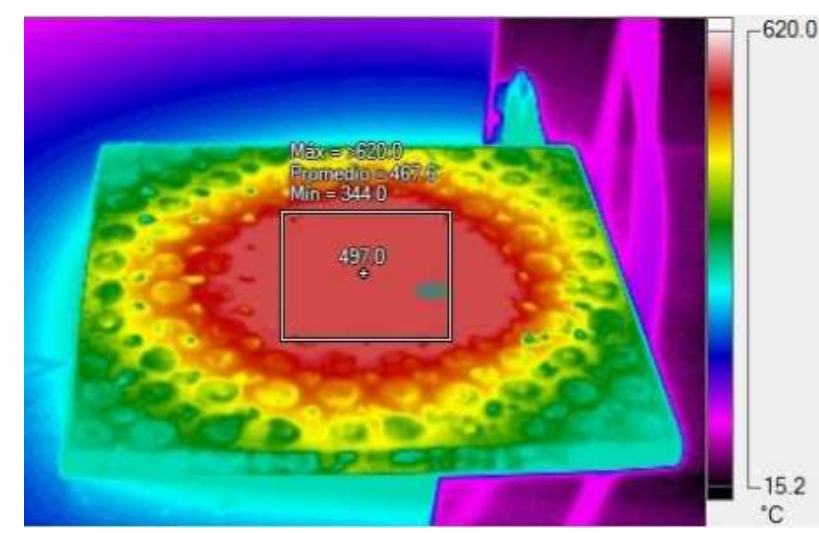

Plate 1

Temperature

maximum $620^{\circ} \mathrm{C}$, minimum $344^{\circ} \mathrm{C}$, average $467.6^{\circ} \mathrm{C}$

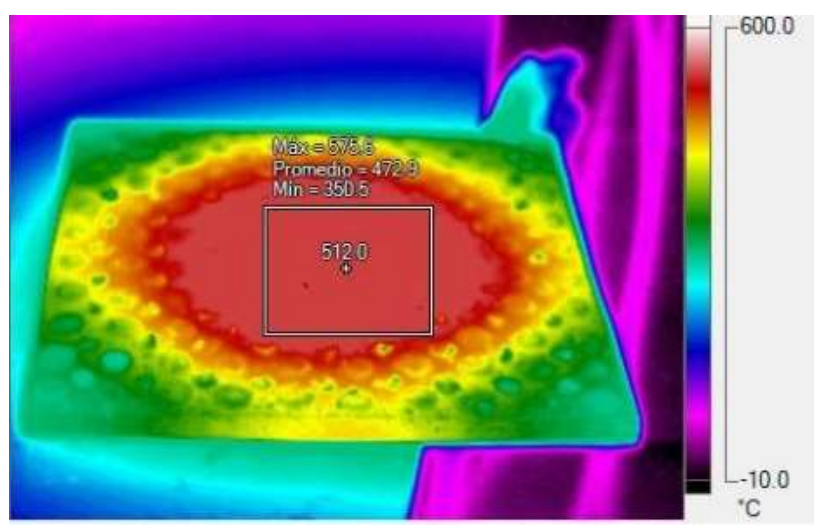

Plate 2

Temperature

maximum $575.6^{\circ} \mathrm{C}$, minimum $350.5^{\circ} \mathrm{C}$, average $472.9^{\circ} \mathrm{C}$

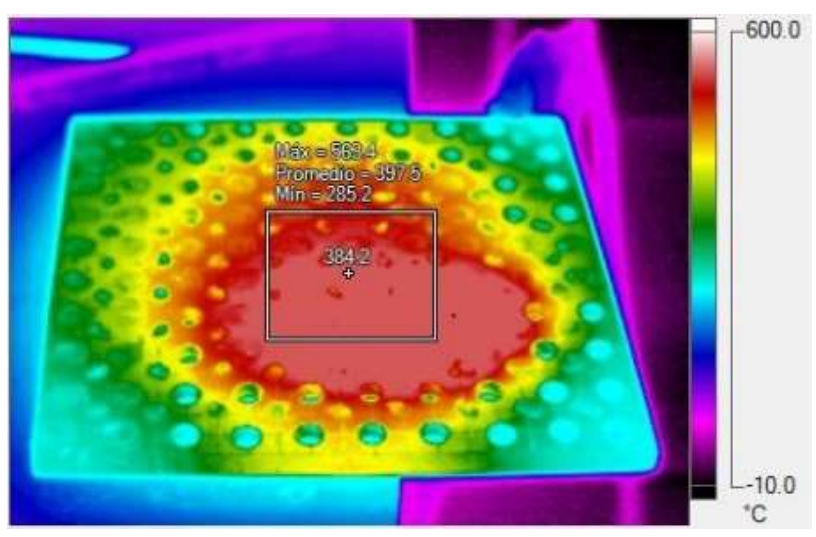

Plate 3

Temperature

maximum $354.2^{\circ} \mathrm{C}, \quad$ minimum $231.9^{\circ} \mathrm{C}$, average $293.7^{\circ} \mathrm{C}$

Figure 10 Thermographic image of plate 1,2,3 corresponding to sequence 5 . The maximum and minimum temperatures reached by solder application concentration are shown

The scatter diagrams used allow obtaining a pattern of points that assumes the shape of a straight line with a slope that represents the deformation-temperature behavior. This means that the lower the slope, the lower the deformation generated. 
This provides a parameter that indicates that the trajectory established in the welding sequence generates a smaller angle in the slope to obtain smaller deformations. Likewise, this application allows obtaining the linear relationship coefficient, providing a measure of the relationship between deformationtemperature; the closer this coefficient is to the absolute unit, the better the behavior of the straight line will be. In Figure 11, the linear regression graphs are shown, where the relationship coefficients obtained are: 0.9518 , 0.9887 and 0.9552 for plates 1,2 and 3 respectively.

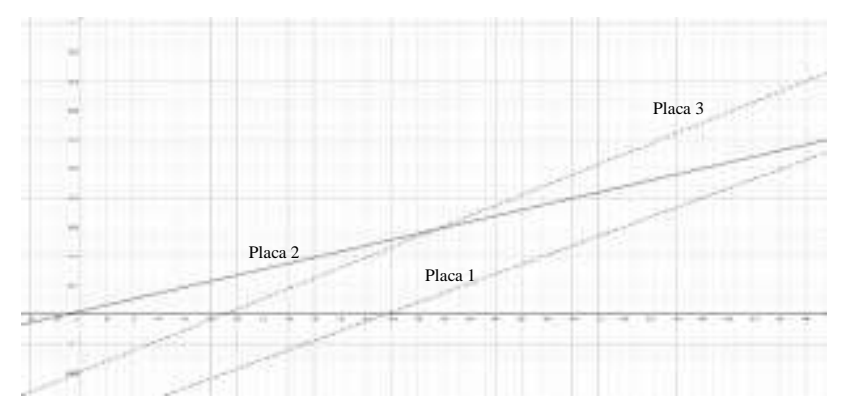

Figure 11 Linear relationship coefficient for plates 1,2 and 3

\section{Conclusions}

It is confirmed that there is a relationship between deformation and temperature increase, due to the heat concentration generated by the welding application, which is a function of the established sequence.

The linear graphs show the deformationtemperature behavior, where the lower slope indicates lower temperature changes and therefore lower deformation, which coincides with the values closer to the absolute unit of the linear coefficient.

The lower the deformation, the better the coefficient of linear relationship of the scatter diagram and the steepness of the slope is also lower.

At higher deformation the slope increases its inclination and the linear relationship coefficient is farther away from the absolute unit.
From the above we can determine that specimen 2 is the one that showed less deformation, which we can see in the linear relationship coefficient and we also observe that the slope is less pronounced than in plate 1 and plate 3.

\section{References}

American Welding Society, Structural welding code AWS D1.1, American National Standards Institute, 2010.

Bullon W. (Diciembre de 2010) Simulación de un proceso de soldadura utilizando un modelo termo-mécanico tridimencional con prescipcion de temperatura. Lima, Perú.

Flores, F.J.G., Guía práctica para prevenir deformaciones por soldadura, in Arquitectura Naval 2006, Universidad Austral de Chile Valdivia Chile p. 53.

Guangming Fu, M.I.L., Menglan Duan, Segen F, Estefen Influence of the welding sequence on residual stress and distortion of fillet welded structures. ELSEVIER, 2015: p. 31.

López de Martínez Edgar, C.I.B.F., Garnica González Pedro, Vergara Hernández, Héctor Javier. , Efecto del calor aportado por soldadura en un acero microaleado. septiembre, 2013 p. 7.

Marconi César, M.J.C., Boccanera Leonardo, Ramini Mabel, Influencia del calor aportado y metal de aporte sobre las propiedades mecánicas y la microestructura de juntas soldadas por fcaw de acero microaleado de alta resistencia. 21 Mayo, 2015: p. 11.

Radaj, D., "Heat Effects of Welding Temperature Field, Residual Stress, Distortion 1992, Bangalore, India.

Weld Distortion (2018), Cleveland Ohio, LinconElectric,http://www.lincolnelectric.com/ en-us/support/welding-how-to/Pages/welddistortion-detail.aspx 